\title{
Identification and quantification of shipping emissions in Bohai Rim, China
}

\author{
Fan Zhang a,b , Yingjun Chen a,*, Chongguo Tian ${ }^{\text {a,* }}{ }^{\text {, }}$ Xiaoping Wang b,c , Guopei Huang a,b, \\ Yin Fang ${ }^{\mathrm{a}, \mathrm{b}}$, Zheng Zong ${ }^{\mathrm{a}, \mathrm{b}}$
}

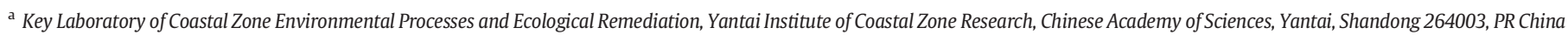

${ }^{\mathrm{b}}$ University of Chinese Academy of Sciences, Beijing 100049, PR China

' State Key Laboratory of Organic Geochemistry, Guangzhou Institute of Geochemistry, Chinese Academy of Sciences, Guangzhou, Guangdong 510640, PR China

\section{H I G H L I G H T S}

- Tracers of shipping emissions in coastal zone of northern China were identified.

- Contributions of shipping emissions on primary $\mathrm{PM}_{2.5}$ were estimated.

- Shipping emissions accounted for $2.94 \%$ of primary $\mathrm{PM}_{2.5}$ apart from fishing boats.

- Impact of shipping emissions on coastal zone increased rapidly in recent years.

\section{A R T I C L E I N F O}

\section{Article history:}

Received 3 June 2014

Received in revised form 5 August 2014

Accepted 6 August 2014

Available online 25 August 2014

Editor P. Kassomenos

\section{Keywords:}

Shipping emissions

$\mathrm{PM}_{2.5}$

Bohai

Coastal zone

Tracers

Quantification

\begin{abstract}
A B S T R A C T
Rapid development of port and shipbuilding industry in China has badly affected the ambient air quality of coastal zone due to shipping emissions. A total of 60 ambient air samples were collected from background site of Tuoji Island in Bohai Sea strait. The air samples were analyzed for $\mathrm{PM}_{2.5}$, organic carbon (OC), element carbon (EC), inorganic elements, and water-soluble ions. The maximum concentration of $\mathrm{PM}_{2.5}$ was observed during spring $\left(73.6 \mu \mathrm{g} \cdot \mathrm{m}^{-3}\right)$ compared to winter $\left(39.0 \mu \mathrm{g} \cdot \mathrm{m}^{-3}\right)$ with mean of $54.6 \mu \mathrm{g} \cdot \mathrm{m}^{-3}$. Back trajectory air mass analysis together with temporal distribution of vanadium $(\mathrm{V})$ showed that $\mathrm{V}$ could be the typical tracer of shipping emissions at Tuoji Island. Furthermore, the ratios of vanadium to nickel $(\mathrm{V} / \mathrm{Ni})$, vanadium to lead $(\mathrm{V} / \mathrm{Pb})$ and vanadium to zinc $(\mathrm{V} / \mathrm{Zn})$ also suggest shipping emissions at Tuoji Island. The annual average primary $\mathrm{PM}_{2.5}$ estimate of shipping emissions was $0.65 \mu \mathrm{g} \cdot \mathrm{m}^{-3}$ at Tuoji Island, accounting for $2.94 \%$ of the total primary $\mathrm{PM}_{2.5}$, with a maximum of $3.16 \%$ in summer and a minimum of $2.39 \%$ in autumn.
\end{abstract}

(c) 2014 Elsevier B.V. All rights reserved.

\section{Introduction}

Recently, air pollution in the North China Plain (NCP) has received considerable public attention because of extent of air quality degradation from local to regional scale and also due to significant increase in respiratory illness (Wu et al., 2014). The NCP, which includes Beijing, Tianjin, and the Hubei province, has become the third largest and most important economic zone after the Yangtze River Delta and the Pearl River Delta in China (Boynard et al., 2014; Tao et al., 2014). The region is listed as one of the most severely polluted areas in the world due to rapid industrialization, important growth in car ownership and largescale agricultural activities. Emission from coal burning, agricultural

\footnotetext{
* Corresponding authors. Tel.: + 865352109 020; fax: + 865352109000.

E-mail addresses: yjchen@yic.ac.cn (Y. Chen), cgtian@yic.ac.cn (C. Tian).
}

activities (including agriculture and synthetic fertilizer production and straw burning in household and field) and motor vehicle exhausts are often highlighted as the main source of air pollution (Cheng et al., 2013; Li et al., 2013). However, the role of shipping emissions from the Bohai Rim always has been neglected, which have a growing impact on NCP in recent years.

Shipping emissions contribute significantly to air pollution in coastal zone and ports. It is estimated that about 0.9 to 1.7 million tons of PM discharged from ships every year, and nearly $70 \%$ of it occur within $400 \mathrm{~km}$ of seas shore (Eyring et al., 2010). There were about 60,000 cases of deaths due to cardiovascular diseases and lung cancer associated with ship emission Corbett et al. (2007). Though, the primary $\mathrm{PM}_{2.5}$ (particulate matters with aerodynamic diameter less than or equal to $2.5 \mu \mathrm{m})$ emitted from ships only account for a low proportion (1.5\% in Cork Harbour e.g.) (Healy et al., 2010) of total $\mathrm{PM}_{2.5}$ in ambient air 
compared with other sources, 3-8\% of deaths associated with $\mathrm{PM}_{2.5}$ emission globally were linked to shipping emission (EPA, 2009). Due to its complex mechanism and high absorption capacity for toxic chemicals, such as polycyclic aromatic hydrocarbons, PM exhausted by ships could cause more serious human health risk than by direct emissions (EPA, 2009). Various researcher across the world reported the contribution of shipping emissions to ambient air pollution (Agrawal et al., 2009; Isakson et al., 2001; Moreno et al., 2009; Pandolfi et al., 2011; Pey et al., 2013). Majority of studies was based on multivariate analysis of $\mathrm{V}$ and Ni which confirmed the tracers of shipping emissions. However, studies about contribution of shipping emissions to ambient air were rare in China, only a few studies in Shanghai port and Hong Kong port had reported the influence of shipping emissions on ports. For example, Zhao et al. (2013a) studied the air quality of Shanghai port, the largest port of China, and found the shipping emissions to ambient air with $\mathrm{V}$ as the tracer of Shanghai port. A recent study by Kwok et al. (2012) showed that about $8-56 \%$ of sulfate pollution in Hong Kong was due to shipping emissions. The high $\mathrm{V} / \mathrm{Ni}$ ratio in $\mathrm{PM}_{2.5}$ observed in urban air of Hong Kong also suggests role of ship emission (Zheng et al., 2011).

Bohai Sea is located adjacent to NCP. With the rapid expansion of industrialization in the NCP, many large coastal ports are created in Bohai Sea. It is estimated that there were 0.18 million water transport vessels (China Statistical Yearbook, 2013) and 1.07 million fishing boats (Chinese Fishery Statistical Yearbook, 2013) active in Chinese seas by 2013, and about $1 / 3$ of which lie in Bohai Sea. In 2010, 12 ports in China were listed as world's largest 20 ports. The number of ports with cargo handling capacity more than one hundred million tons per year had reached to 22 by 2010, half of which are located in the Bohai Rim (Report on China Shipping Development, 2010). The concentration of vanadium (often referred to emissions from heavy oil) in $\mathrm{PM}_{2.5}$ observed at Jeju Island in Korea had been rapidly risen from 1.1 to $8.5 \mathrm{ng} \cdot \mathrm{m}^{-3}$ during 2001 to 2006 (Kim et al., 2006; Moon et al., 2008; Nguyen et al., 2009). Vanadium concentration largely attributed to the increase of ship emission around the sea waters. However, little attention has been paid to the contribution of shipping emissions to regional atmospheric pollution despite frequent shipping activities in Bohai Rim. Hence, in the present study, we analyze the ambient air samples from Bohai Sea to assess the concentrations and chemical compositions of $\mathrm{PM}_{2.5}$. Further, the sources of tracers of shipping emissions were identified using HYSPLIT model, and their influences on ambient air in the coastal zone of NCP were quantified.

\section{Methodology}

\subsection{Sampling site and sampling}

The sampling site is located in northwestern tip of the Tuoji Island where national platform station for monitoring for background atmospheric air has been set-up. Tuoji Island situated in the middle of Bohai strait (Fig. 1) at a distance of about $40 \mathrm{~km}$ and $70 \mathrm{~km}$ from Penglai and Dalian, respectively. There are several water channels around Tuoji Island, such as Laotieshan water channel, Changbaishan water channel and Miaodao Strait. Besides, many large ports are distributed in the Bohai Rim including Dalian port, Yingkou port, Tianjin port, Qinhuangdao port and Qingdao port. Though there are no direct shipping emissions from ports at Tuoji Island, there is possibility that the $\mathrm{PM}_{2.5}$ in the ambient air can be influenced to some extent, by the long-distance transport from ports and on-going ships.

The sampling campaign was conducted at Tuoji Island during November, 2011. Since, the sampling site is located on the top of the highest mountain (about $153 \mathrm{~m}$ above sea level) and about $3 \mathrm{~km}$ away from local settlement, the collected samples rarely influenced by local sources. Ambient air containing $\mathrm{PM}_{2.5}$ samples were collected at Tuoji Island on quartz fiber filters (Whatman, QM-A, $8 \times 10$ in., heated at $500{ }^{\circ} \mathrm{C}$ for $4 \mathrm{~h}$ before use) with a high-volume sampler (Hi-Vol 3000 , Ecotech Company, Australia). The flow rate was $1.13 \mathrm{~m}^{3} \cdot \mathrm{min}^{-1}$ and the sampling time was nominally $24 \mathrm{~h}$. All the filters were placed in a box of constant temperature and humidity for $24 \mathrm{~h}$ under the condition of $25{ }^{\circ} \mathrm{C}$ and $50 \%$ relative humidity ( $\mathrm{RH}$ ) both before and after sampling. A total of 60 samples were collected from Jan to Dec, 2012 with average of 5 samples each month (usually, we take Match to May as spring, June to August as summer, September to November as autumn and December to February as winter, so 15 samples were selected for each season). According to the National Standards of PRC (GB 3095-2012), an annual average value is valid if there are at least 60 samples of daily average values that had equally distributed, and the same, a monthly average value is valid if there are at least 5 samples of daily average values that had equally distributed.

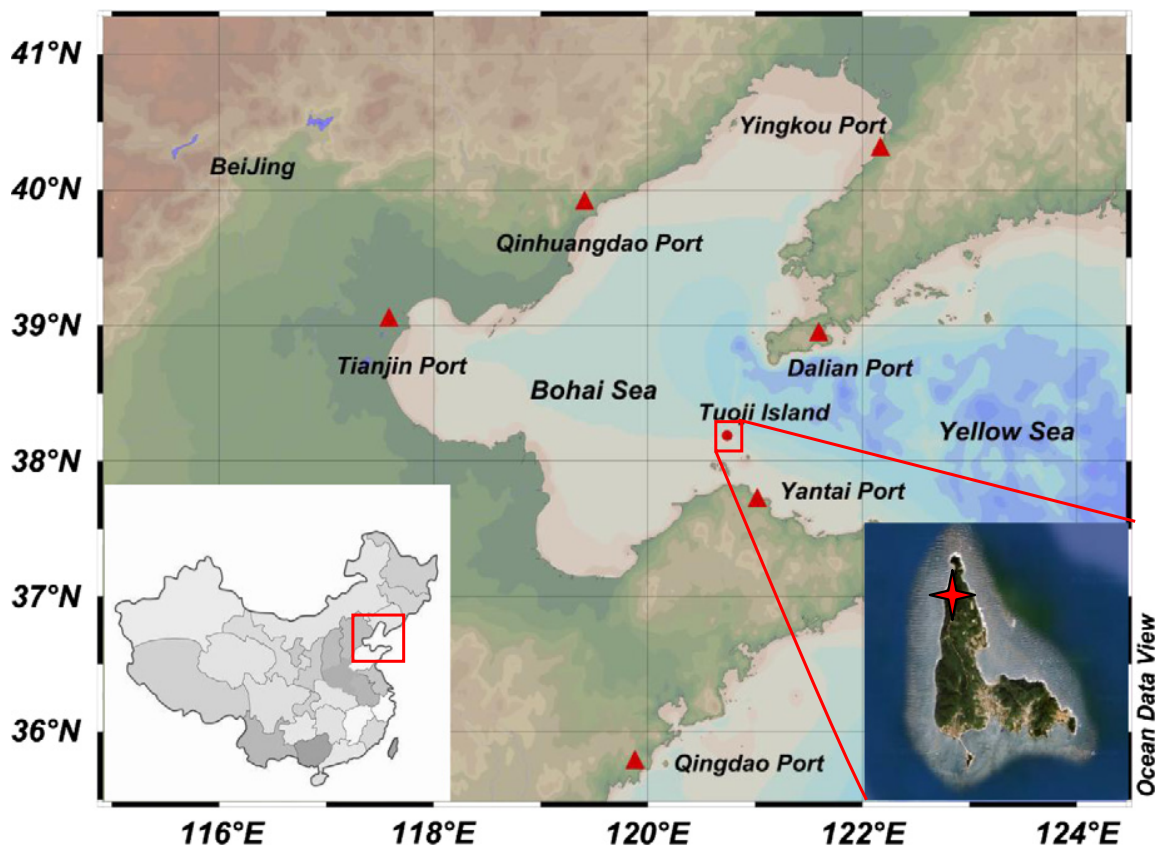

Fig. 1. Sampling site of Tuoji Island and the location of big ports in circum-Bohai-Sea. 


\subsection{Chemical analysis and quality control}

\subsubsection{Chemical analysis}

The OC and EC were measured on a $0.544 \mathrm{~cm}^{2}$ punch from each filter by thermal optical reflectance (TOR) following the IMPROVE protocol with a DRI Model 2001 Thermal/Optical Carbon Analyzer (Atmoslytic Inc., Calabasas, CA). The measuring range of TOR was from 0.05 to $750 \mu \mathrm{g} \mathrm{C} / \mathrm{cm}^{2}$ with the error less than $10 \%$. The concentrations of water soluble ions in $\mathrm{PM}_{2.5}$, such as $\mathrm{Na}^{+}, \mathrm{NH}_{4}^{+}, \mathrm{K}^{+}, \mathrm{Mg}^{2+}, \mathrm{Ca}^{2+}, \mathrm{Cl}^{-}$, $\mathrm{NO}_{3}^{-}$and $\mathrm{SO}_{4}^{2-}$, were determined by ion chromatograph (Dionex ICS3000, Dionex Ltd., America) based on the measurement method of Shahsavani et al. (2012). The detection limit was $10 \mathrm{ng} / \mathrm{ml}$ with the error less than $5 \%$, and $1 \mathrm{ml} \mathrm{RbBr}$ of $200 \mathrm{ppm}$ was put in the solution as internal standard before sampling. The concentrations of 33 inorganic elements in $\mathrm{PM}_{2.5}$ were estimated using inductively coupled plasma coupled with mass spectrometer (ICP-MS of ELAN DRC II type, Perkin Elmer Ltd., Hong Kong) following the standard method (Wang et al., 2006). The resolution of ICP-MS ranged from 0.3 to $3.0 \mathrm{amu}$ with a detection limit lower than $0.01 \mathrm{ng} / \mathrm{ml}$, and the error was less than $5 \%$. Element indium (In) of $5 \mathrm{ppb}$ was put in the solution before sampling as the internal standard.

\subsubsection{Quality control}

Strict quality control was followed for the analytical methods during the whole experimental process. A duplicate sample for every 10 samples with less than $5 \%$ relative average deviation between the sample and the duplicate sample was obtained. Besides, one standard was measured after every 20 samples to make sure the error between the measured concentration and the theoretical concentration was within $\pm 5 \%$.

\subsection{Modeling}

The HYbrid Single-Particle Lagrangian Integrated Trajectory (HYSPLIT) model is a complete system for computing simple air parcel trajectories to complex dispersion and deposition simulations. Back trajectory analyses use modeled meteorological fields to estimate the most likely central path over geographical areas that provided air to a receptor at a given time, which can be used to speculate the source of PM in samples. Another function of HYSPLIT used in this study was cluster analysis, which can classify multiple air mass trajectories as several trajectories that have similar movement directions and rates each using the K-means cluster analysis.

Four seasons' cluster-mean trajectories of year 2012 at Tuoji Island were given in Fig. 2 using HYSPLIT combined with GDAS meteorological data obtained from University of Alaska Fairbanks (University of Alaska Fairbanks GDAS Archive). The back trajectories were calculated for $72 \mathrm{~h}$ before the air mass arrived in Tuoji Island $\left(38.17^{\circ} \mathrm{E}, 120.76^{\circ} \mathrm{N}\right)$ with an initial height $500 \mathrm{~m}$, four trajectories were given every day $(00,06,12$, 18 , UTC). The results showed that most of the air masses passed inland of northwest of China and Shandong Peninsula except for summer, which mainly passed the Bohai and East China Seas.

\section{Results and discussion}

\subsection{Concentration of $\mathrm{PM}_{2.5}$ and chemical compositions at Tuoji Island}

The concentrations of $\mathrm{PM}_{2.5}$ and their chemical compositions in four seasons at Tuoji Island are listed in Table 1. The concentrations of $\mathrm{PM}_{2.5}$ ranged from $17.3 \mu \mathrm{g} \cdot \mathrm{m}^{-3}$ to $143.8 \mu \mathrm{g} \cdot \mathrm{m}^{-3}$ (mean $54.6 \mu \mathrm{g} \cdot \mathrm{m}^{-3}$ ), which is higher than the Ambient Air Quality Standard of China (annual mean:
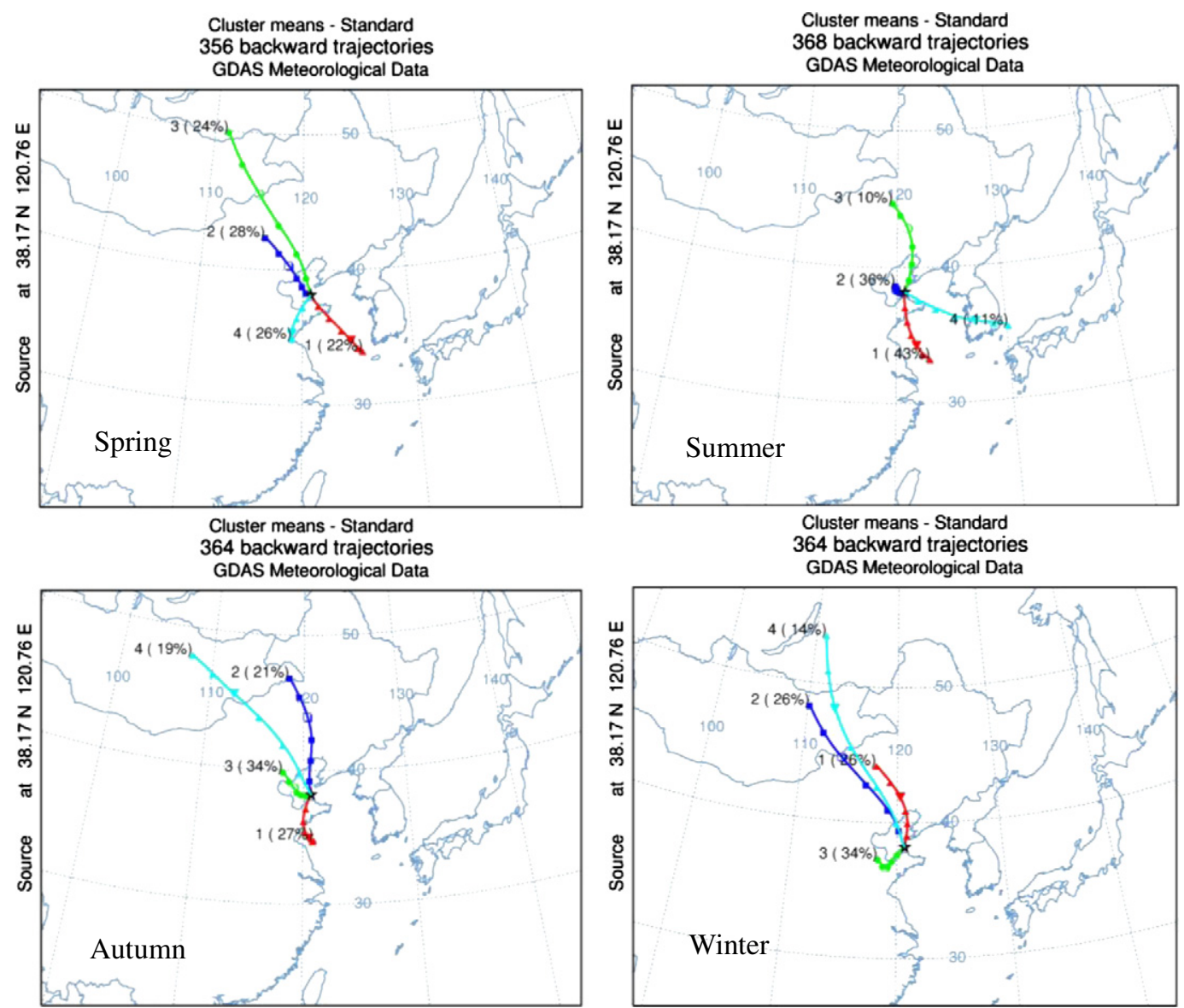

Fig. 2. Cluster-mean trajectories of year 2012 in Tuoji Island. 
Table 1

Chemical compositions of $\mathrm{PM}_{2.5}$ at Tuoji Island (values of $\mathrm{PM}_{2.5}, \mathrm{OC}, \mathrm{EC}, \mathrm{SO}_{4}^{2-}, \mathrm{NH}_{4}^{+}$and $\mathrm{NO}_{3}^{-}$in $\mu \mathrm{g} \cdot \mathrm{m}^{-3}$, others in $\mathrm{ng} \cdot \mathrm{m}^{-3}$ ).

\begin{tabular}{|c|c|c|c|c|c|}
\hline & Spring & Summer & Autumn & Winter & Annual \\
\hline & Mean $\left(\mathrm{SD}^{1}\right)$ & Mean (SD) & Mean (SD) & Mean (SD) & Mean (SD) \\
\hline $\mathrm{PM}_{2.5}$ & $73.6(29.2)$ & 60.7 (39.9) & $44.6(27.6)$ & $48.5(25.7)$ & $54.6(34.0)$ \\
\hline OC & $4.79(4.61)$ & $3.55(1.82)$ & $5.55(4.79)$ & $5.27(2.67)$ & $5.07(3.67)$ \\
\hline $\mathrm{EC}$ & $1.64(1.19)$ & $2.25(1.15)$ & $2.63(1.79)$ & $1.97(1.12)$ & $2.03(1.36)$ \\
\hline $\mathrm{SO}_{4}^{2-}$ & $10.7(5.60)$ & $16.7(17.4)$ & $8.90(7.40)$ & $5.70(5.10)$ & $10.5(10.9)$ \\
\hline $\mathrm{NH}_{4}^{+}$ & $2.10(0.60)$ & $2.10(1.10)$ & $1.50(0.90)$ & $1.40(0.80)$ & $1.80(0.90)$ \\
\hline $\mathrm{NO}_{3}^{-}$ & $10.7(6.10)$ & $4.60(5.20)$ & $5.90(6.30)$ & $5.80(5.30)$ & $6.80(6.20)$ \\
\hline $\mathrm{Na}^{+}$ & 354 (113) & $306(121)$ & 447 (238) & $315(122)$ & 379 (183) \\
\hline $\mathrm{K}^{+}$ & 777 (364) & 913 (1199) & $666(431)$ & $546(413)$ & 725 (699) \\
\hline $\mathrm{Mg}^{2+}$ & $34.5(25.2)$ & $21.0(13.6)$ & $31.4(38.7)$ & $18.7(21.1)$ & $26.4(27.8)$ \\
\hline $\mathrm{Ca}^{2+}$ & $598(515)$ & 179 (157) & 345 (526) & $284(286)$ & 351 (431) \\
\hline $\mathrm{Cl}^{-}$ & $653(665)$ & 275 (449) & 296 (407) & $537(660)$ & $440(536)$ \\
\hline $\mathrm{Na}$ & 627 (406) & $2506(2270)$ & $2031(1472)$ & 747 (667) & $1478(1625)$ \\
\hline $\mathrm{Mg}$ & $212(146)$ & 107 (139) & $168(190)$ & $120(100)$ & $152(152)$ \\
\hline $\mathrm{K}$ & $592(322)$ & 928 (1495) & $608(681)$ & $425(310)$ & $638(873)$ \\
\hline $\mathrm{Fe}$ & $728(553)$ & 331 (537) & 468 (517) & 339 (335) & 466 (519) \\
\hline $\mathrm{Ca}$ & 478 (379) & 288 (419) & 335 (430) & 247 (231) & 337 (383) \\
\hline $\mathrm{Mn}$ & $373(230)$ & 257 (482) & 303 (292) & $219(152)$ & 288 (319) \\
\hline $\mathrm{Pb}$ & $87.3(60.2)$ & $100(237)$ & 120 (129) & $59.5(56.3)$ & 91.7 (143) \\
\hline $\mathrm{Zn}$ & $104(77.2)$ & $123(278)$ & $103(103)$ & $47.0(30.0)$ & 94.3 (157) \\
\hline As & $4.50(2.50)$ & $5.50(11.2)$ & $4.00(4.90)$ & $3.40(2.00)$ & $4.30(6.40)$ \\
\hline V & $8.30(4.60)$ & $7.50(5.00)$ & $4.70(5.10)$ & $3.60(2.90)$ & $6.00(4.90)$ \\
\hline $\mathrm{Cr}$ & $5.70(4.70)$ & $4.10(2.30)$ & $4.30(1.10)$ & $1.90(0.40)$ & $4.00(1.30)$ \\
\hline $\mathrm{Ni}$ & $5.40(2.30)$ & $4.90(5.10)$ & $3.20(3.30)$ & $2.40(1.70)$ & $4.00(3.60)$ \\
\hline $\mathrm{Cu}$ & $13.1(8.7)$ & $18.9(40.8)$ & $11.2(13.5)$ & $7.40(5.60)$ & $12.6(22.6)$ \\
\hline $\mathrm{Cd}$ & $1.20(0.50)$ & $1.50(2.30)$ & $1.50(1.10)$ & $1.00(0.40)$ & $1.30(1.30)$ \\
\hline
\end{tabular}

1 SD: standard deviation.

$\left.35 \mu \mathrm{g} \cdot \mathrm{m}^{-3}\right)$. Maximum concentration of $\mathrm{PM}_{2.5}$ was observed in December $\left(27.4 \mu \mathrm{g} \cdot \mathrm{m}^{-3}\right)$ while March $\left(87.6 \mu \mathrm{g} \cdot \mathrm{m}^{-3}\right)$ received less $\mathrm{PM}_{2.5}$. Also, high concentration of $\mathrm{PM}_{2.5}$ was found in spring $\left(73.6 \mu \mathrm{g} \cdot \mathrm{m}^{-3}\right)$, followed by summer $\left(60.7 \mu \mathrm{g} \cdot \mathrm{m}^{-3}\right)$, and winter $\left(39.0 \mu \mathrm{g} \cdot \mathrm{m}^{-3}\right)$. Unlikely, Cao et al. (2012) found high level of $\mathrm{PM}_{2.5}$ in winter compared to summer in other regions in China. This is because the Northwest wind is the prevailing wind in spring and winter with a larger wind-speed in Bohai Sea. Particulate matters such as fine sand flying up in the air from northwest of China and pollutants originated from NCP in spring, which could affect the concentrations and chemical compositions of $\mathrm{PM}_{2.5}$ at Tuoji Island through long-distance transport. However, it always have much more snow in Bohai Sea area than other regions with the same latitude in winter (http://qq.ip138.com/weather/ shandong/ChangDao_history.htm) and the wet sedimentation effect was obvious at Tuoji Island which led to a lower concentration of $\mathrm{PM}_{2.5}$ than other regions. There were 11, 4 and 17 days of snowfall at Tuoji Island in Jan., Feb. and Dec. 2012, respectively, however, only 1, 0 and 6 days that had snowfall at the same time in Beijing that at the same latitude. Took December for example, five samples were collected which were on December 1 to 2, December 8 to 9, December 12 to 13, December 20 to 21 and December 25 to 26, respectively. From the meteorological data we can see that, there were snowfall on December 2, 8 , 13,20 , and 25 , respectively, which could have influence on the concentration of $\mathrm{PM}_{2.5}$ at Tuoji Island.

Sulfate, organic matters (OM), nitrate and main metal oxides (MMO) were the most important chemical compositions in $\mathrm{PM}_{2.5}$ at Tuoji Island, account for $18.8 \%, 16.5 \%, 10.8 \%$ and $9.4 \%$ of total mass of $\mathrm{PM}_{2.5}$, respectively, followed by ammonium (3.5\%) and elemental carbon (3.3\%). Though $\mathrm{V}$ and Ni only account for very small parts of $\mathrm{PM}_{2.5}$ mass, $0.11 \%$ and $0.07 \%$ in this study, they had very important roles in tracing contribution of shipping emissions to ambient air.

\subsection{Identification of shipping emissions at Tuoji Island}

\subsubsection{Typical tracers of shipping emissions}

Generally, $\mathrm{V}$ and $\mathrm{Ni}$ are typically associated with the combustion of heavy fuel oil (Almeida et al., 2005; Harrison et al., 1996), almost 100\% of the atmospheric vanadium is considered coming from oil combustion (Pacyna et al., 1984), and when the ratio of $\mathrm{V}$ to $\mathrm{Ni}$ is higher than 0.7, it always considered being influenced by shipping emissions (Isakson et al., 2001). In this study, variations of $\mathrm{V}, \mathrm{Ni}$ and ratio of $\mathrm{V}$ to $\mathrm{Ni}$ in $\mathrm{PM}_{2.5}$ at Tuoji Island in 2012 were showed in Fig. 3. As shown, $\mathrm{V}$ and $\mathrm{Ni}$ had the familiar concentration variations with a correlation coefficient of 0.91 . Both of them had low values in autumn and winter, high values in spring and summer. The low values were concentrated during November to December and the high values March to August. Considering the climate conditions of the Bohai Sea area, there was relatively lower wind speed in spring and summer, which were more suitable for shipping. Furthermore, with the development of tourism of islands such as Changdao and other islands around Tuoji Island, ro-ro ships and ferry ships were more active in summer, and both of the reasons caused the higher values of $\mathrm{V}$ and $\mathrm{Ni}$ in summer. While, large area of sea ice often occurred in Bohai Sea with heavy snowstorm and strong wind in winter that made it hard for shipping, which led to the lower values of $\mathrm{V}$ and $\mathrm{Ni}$.

As the typical tracer of shipping emissions mentioned in literatures, $\mathrm{V} / \mathrm{Ni}$ had a statistical value of 0.7 in industrial sources, but it would be apparently higher than this value in coastal areas (Isakson et al., 2001). The annual average ratio of $\mathrm{V} / \mathrm{Ni}$ at Tuoji Island was 1.54 with the majority of values higher than 0.7 . And there were higher values during later spring to summer, lower values in winter, which were consistent with the temporal variations of $\mathrm{V}$ and $\mathrm{Ni}$. Zhao et al. (2013a) had analyzed the chemical compositions of heavy fuel oil used in Shanghai port, which showed that the mean ratio of $\mathrm{V} / \mathrm{Ni}$ was 1.9 in heavy fuel oil. The ratio of $\mathrm{V} / \mathrm{Ni}$ at Tuoji Island was a little lower than that, but much higher than industrial sources (Isakson et al., 2001).

Further, to assess the relationship of $\mathrm{V}$ and shipping emissions at Tuoji Island, trajectories of high concentrations of $\mathrm{V}$ (data points above the third quartile) and low concentrations of $\mathrm{V}$ (data points below the first quartile) were analyzed using the K-means cluster analysis of HYSPLIT. Results were shown in Fig. 4. The vast majority of trajectories of high concentrations came from or passed through Bohai Sea, Yellow Sea and East China Sea, while of low concentrations, most of them came from northwest of China through long-distance transport except a fraction from Shandong Peninsula. The trajectories with high concentrations from seas indicate the influence of shipping emissions on air quality at Tuoji Island.

In order to exclude the influence of $\mathrm{V}$ from transport of inland, we had compared the concentrations of $\mathrm{V}$ and ratios of $\mathrm{V} / \mathrm{Ni}$ with several cities in the Bohai Rim, such as Beijing and Tianjin. As mentioned in Fig. 2, most of the air mass came from northwest of China such as NCP and Shandong Peninsula. NCP is one of the most polluted areas in China, so we took Tianjin (Gu et al., 2011) in winter for example in this study. The concentration of $\mathrm{PM}_{2.5}$ could reach $144.6 \mu \mathrm{g} \cdot \mathrm{m}^{-3}$ with an average concentration $2.2 \mathrm{ng} \cdot \mathrm{m}^{-3}$ of $\mathrm{V}$, which was much lower than Tuoji Island both in concentration and the proportion to $\mathrm{PM}_{2.5}$. Other studies (Zhao et al., 2013b) in the NCP also had the same results. All the ratios of V/Ni in NCP were much lower than 0.7 , such as 0.01 of Tianjin in winter (Gu et al., 2011) and 0.24 of Beijing in annual average (Zhao et al., 2013b).

\subsubsection{Other potential tracers of shipping emissions}

As is well-known, heavy fuel oil is the most common fuel of ships; there are large amounts of $\mathrm{SO}_{2}, \mathrm{NO}_{\mathrm{x}}$ and organic matter in exhaust of ships, and some of these matters can translate into sulfate, nitrate and second organic aerosols (SOA) through secondary reaction in atmosphere. Besides, $\mathrm{Pb}$ and $\mathrm{Zn}$ were also reported to connect with shipping emissions (Brimblecombe, 1996). So, in this study, we analyzed the correlations of $\mathrm{V}$ with matters that had relationship with shipping emissions, such as $\mathrm{OC}, \mathrm{EC}, \mathrm{Ni}, \mathrm{Zn}, \mathrm{Pb} \mathrm{NH}_{4}^{+}, \mathrm{NO}_{3}^{-}$and $\mathrm{SO}_{4}^{2-}$, the results were shown in Table 2. $\mathrm{Ni}, \mathrm{Zn}, \mathrm{Pb}^{-} \mathrm{NH}_{4}^{+}$and $\mathrm{SO}_{4}^{2-}$ had correlations with $\mathrm{V}$ at a 99\% confidence interval level (bilateral). It is well known that $\mathrm{NH}_{4}^{+}$, $\mathrm{NO}_{3}^{-}$and $\mathrm{SO}_{4}^{2-}$ are typical secondary aerosols, $\mathrm{SO}_{4}^{2-}$ and $\mathrm{NO}_{3}^{-}$in $\mathrm{PM}_{2.5}$ 


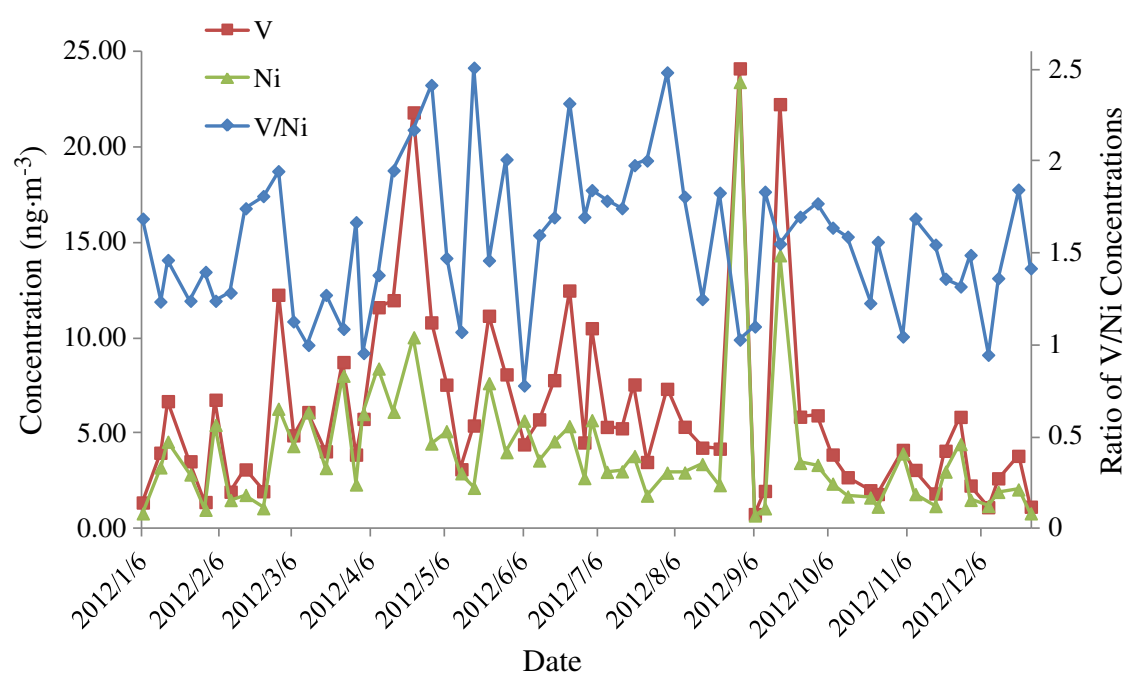

Fig. 3. Temporal variations of $\mathrm{V}$ and Ni concentrations and their ratio at Tuoji Island.

are mainly from power sector and industry sector in China (Zhang et al., 2012), and $\mathrm{NH}_{4}^{+}$is mainly from livestock breeding and farming ( $\mathrm{Yu}$, 2007), shipping emissions had much less influence on $\mathrm{PM}_{2.5}$ than these sources that transport through long-distance from NCP at Tuoji Island. It was difficult for us to distinguish shipping emissions from them, $\mathrm{so} \mathrm{NH}_{4}^{+}, \mathrm{NO}_{3}^{-}$and $\mathrm{SO}_{4}^{2-}$ could not be tracers of shipping emissions though they had certain correlations with $\mathrm{V}$ in this study.

The concentrations of $\mathrm{Pb}, \mathrm{Zn}$ and the ratios of $\mathrm{V} / \mathrm{Pb}, \mathrm{V} / \mathrm{Zn}$ at Tuoji Island were shown in Fig. 5. The variations of concentration of $\mathrm{Pb}$ and $\mathrm{Zn}$ had a similar trend, and both of them had low values in the period from May to July, but had a sudden increase in August, then decreased gradually. Almost all of the concentrations of $\mathrm{Pb}$ and $\mathrm{Zn}$ in this study were lower than that of inland studies (Han et al., 2010). Conversely, both of the ratios of $\mathrm{V} / \mathrm{Pb}$ and $\mathrm{V} / \mathrm{Zn}$ had high values in spring and summer at Tuoji Island, which showed the similar trends of V. Concentrations of $\mathrm{V}, \mathrm{Pb}, \mathrm{Zn}$ and the ratios of $\mathrm{V} / \mathrm{Pb}$ and $\mathrm{V} / \mathrm{Zn}$ in $\mathrm{PM}_{2.5}$ of several typical northern cities in China were compared with that of Tuoji Island, and the results were shown in Table 3. When there were high or low values of $\mathrm{V}$ in this study, the average ratios of $\mathrm{V} / \mathrm{Pb}$ were 0.27 and 0.11 , respectively, which were both much bigger than inland ratios. The shipping emissions were considered as the main reason for the high values, and when the ratio of $\mathrm{V} / \mathrm{Pb}$ was higher than 0.27 at Tuoji Island, there were obvious effect of shipping emissions; or else, when the ratio of $\mathrm{V} / \mathrm{Pb}$ was lower than 0.11 , it was hardly affected by shipping emissions. Similarly, when there were high or low values of $V$ at Tuoji Island, the average ratios of $\mathrm{V} / \mathrm{Zn}$ were 0.26 and 0.09 , respectively, which were also much higher than inland ratios. It was also considered that when the ratio of $\mathrm{V} / \mathrm{Zn}$ was higher than 0.26 at Tuoji Island, there were obvious effect of shipping emissions; or else, when the ratio of $\mathrm{V} / \mathrm{Zn}$ was lower than 0.09 , it was hardly affected by shipping emissions. In all, we considered that when the ratio of $\mathrm{V} / \mathrm{Pb}$ or $\mathrm{V} / \mathrm{Zn}$ was higher than 0.27 or 0.26 , shipping emissions could have obvious influence on $\mathrm{PM}_{2.5}$ of Tuoji Island, and when the ratio was lower than 0.11 or 0.09 , shipping emissions could be neglected.

The main components of $\mathrm{PM}_{2.5}\left(\mathrm{NH}_{4}^{+}\right.$and $\left.\mathrm{SO}_{4}^{2-}\right)$ were positively correlated with $\mathrm{V}$ indicating their similar source of emission mainly from biomass combustion of Shandong Peninsula and industrial emissions in the Bohai Rim through long-distance transport. Because of their multi-source characteristics, $\mathrm{NH}_{4}^{+}$and $\mathrm{SO}_{4}^{2-}$ cannot be treated as typical tracers of shipping emissions at Tuoji Island.

\subsection{Quantification of shipping emissions to $P M_{2.5}$ at Tuoji Island}

Combustion of residual fuel oils and coal in industrialized economies is recognized as the major source of anthropogenic vanadium (Hope, 2008), and more than $85 \%$ of vanadium in the atmosphere of China is considered from residual fuel oils (Zheng and Twng, 2012). In this study, we assumed that $85 \%$ of $\mathrm{V}$ in $\mathrm{PM}_{2.5}$ was from residual fuel oils
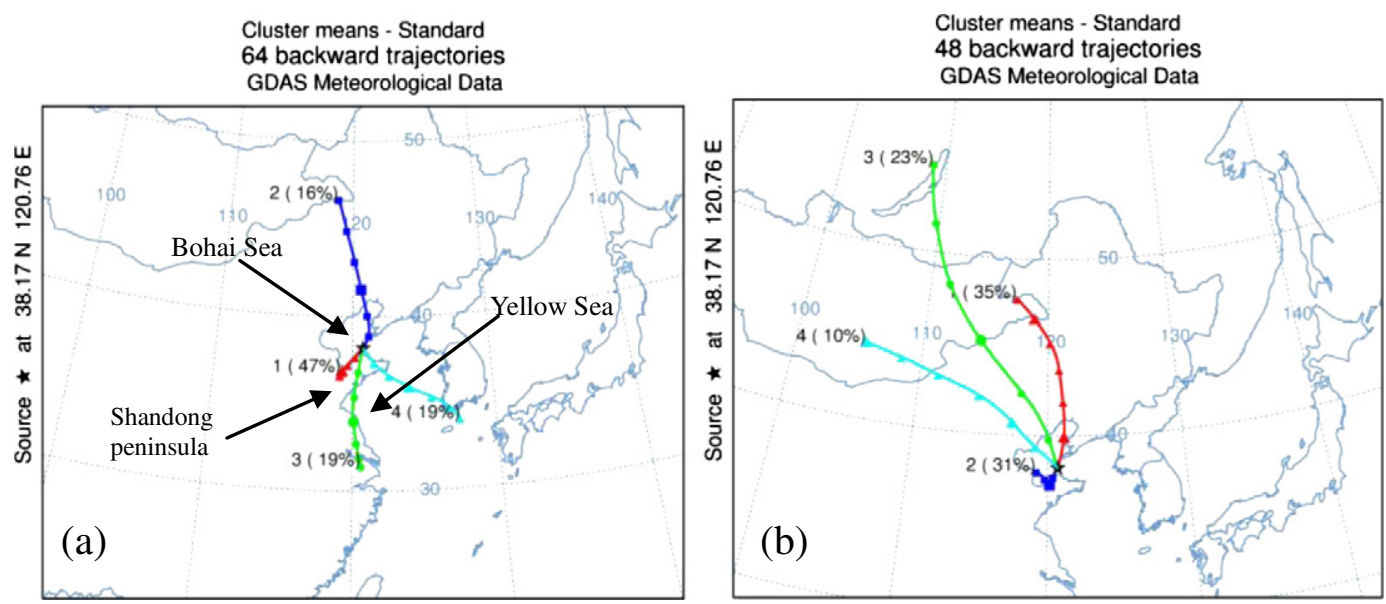

Fig. 4. Cluster-mean trajectories of high (a) and low (b) concentrations of V at Tuoji Island. 
Table 2

Correlations of $\mathrm{V}$ with matters related with shipping emissions.

\begin{tabular}{rllllllll}
\hline & $\mathrm{OC}$ & $\mathrm{EC}$ & $\mathrm{Ni}$ & $\mathrm{Zn}$ & $\mathrm{Pb}$ & $\mathrm{NH}_{4}^{+}$ & $\mathrm{NO}_{3}^{-}$ & $\mathrm{SO}_{4}^{2-}$ \\
\hline $\mathrm{r}$ & 0.03 & 0.14 & $0.91^{* *}$ & $0.61^{* *}$ & $0.59^{* *}$ & $0.59^{* *}$ & $0.26^{*}$ & $0.64^{* *}$ \\
\hline ** & Significant correlation on 0.01 level (bilateral). \\
$*$ & Significant correlation on 0.05 level (bilateral). & & &
\end{tabular}

of shipping emissions. In order to quantify the contribution of shipping emissions to $\mathrm{PM}_{2.5}$ at Tuoji Island, a simple model developed by Agrawal et al. (2009) were used in this study:

$\mathrm{PM}_{\mathrm{a}}=<\mathrm{a}>\times<\mathrm{r}>\times \mathrm{V}_{\mathrm{a}} /<\mathrm{F}_{\mathrm{V}}, \mathrm{HFO}>$

where $<\mathrm{a}>$ is a coefficient of the proportion of $\mathrm{V}$ from ship emissions in $\mathrm{PM}_{2.5}$ in China, and the value was 0.85 in this study, $\mathrm{PM}_{\mathrm{a}}$ is primary $\mathrm{PM}_{2.5}$ concentration estimate $\left(\mu \mathrm{g} \cdot \mathrm{m}^{-3}\right), \mathrm{r}$ is average ratio of $\mathrm{PM}_{2.5}$ to normalized $\mathrm{V}$ emitted $(\mathrm{ppm}), \mathrm{V}_{\mathrm{a}}$ is ambient $\mathrm{V}$ concentration $\left(\mu \mathrm{g} \cdot \mathrm{m}^{-3}\right)$ in sampling site, and $F_{V}$, HFO is average $V$ content of the heavy fuel oil from vessels (ppm). In this study, value of $<\mathrm{r}>$ was $8205.8 \mathrm{ppm}$ according to Agrawal et al. (2009), and the value of $<\mathrm{FV}, \mathrm{HFO}>$ was $65.3 \mathrm{ppm}$ referred to the average vanadium content in the $25 \mathrm{HFO}$ samples collected from China Marine Bunker by Zhao et al. (2013a). To quantify the contribution of primary $\mathrm{PM}_{2.5}$ estimate $\left(\mathrm{PM}_{\mathrm{a}}\right)$ to primary $\mathrm{PM}_{2.5}$ in the ambient air, the main secondary components such as $\mathrm{NH}_{4}^{+}, \mathrm{NO}_{3}^{-}, \mathrm{SO}_{4}^{2-}$ and SOA (Duan et al., 2007) were neglected. Fig. 6 shows the monthly concentration of primary $\mathrm{PM}_{2.5}$ estimate and its contribution to primary $\mathrm{PM}_{2.5}$ at Tuoji Island.

The primary $\mathrm{PM}_{2.5}$ estimate was ranged from $0.23 \mu \mathrm{g} \cdot \mathrm{m}^{-3}$ to $1.33 \mu \mathrm{g} \cdot \mathrm{m}^{-3}$ with an average concentration of $0.65 \mu \mathrm{g} \cdot \mathrm{m}^{-3}$ (minimum of $0.08 \mu \mathrm{g} \cdot \mathrm{m}^{-3}$ and maximum of $2.57 \mu \mathrm{g} \cdot \mathrm{m}^{-3}$ ) at Tuoji Island. Using the similar method, Zhao et al. (2013a) estimated that $\mathrm{PM}_{2.5}$ estimate levels ranged from $0.63 \mu \mathrm{g} \cdot \mathrm{m}^{-3}$ to $3.58 \mu \mathrm{g} \cdot \mathrm{m}^{-3}$ on Shanghai Port, which is slightly higher than that at Tuoji Island. The primary $\mathrm{PM}_{2.5}$ estimate accounted for $0.40 \%$ to $11.76 \%$ of total primary $\mathrm{PM}_{2.5}$ at Tuoji Island, and the monthly average contribution was ranged from $1.33 \%$ to $5.40 \%$, with an average contribution of $2.94 \%$. The contribution of heavy fuel oil to $\mathrm{PM}_{2.5}$ in Hong Kong port was $17 \%$ assessed by Principal component analysis (PCA) (Guo et al., 2009).

The primary $\mathrm{PM}_{2.5}$ estimate about shipping emissions to total $\mathrm{PM}_{2.5}$ at Tuoji Island was lower than other regions. In addition to the differences of calculation methods, it always had a decreased trend of contribution of shipping emissions to $\mathrm{PM}_{2.5}$ with far away from the port. In addition, a study (Agrawal et al., 2009) had shown that the contribution of primary $\mathrm{PM}_{2.5}$ estimate of shipping emissions to total $\mathrm{PM}_{2.5}$ in ambient air was rapidly decreased from $8.8 \%$ to $1.4 \%$ when it came from the port to $80 \mathrm{~km}$ away from the port. Because there were much more ships in port and the exhaust emissions had direct influence on
Table 3

Concentrations of $\mathrm{Pb}, \mathrm{Zn}$ and the ratios of $\mathrm{V} / \mathrm{Pb}, \mathrm{V} / \mathrm{Zn}$ in $\mathrm{PM}_{2.5}$ of northern cities in China.

\begin{tabular}{lcllll}
\hline & $\begin{array}{l}\mathrm{V} \\
\left(\mathrm{ng} \cdot \mathrm{m}^{-3}\right)\end{array}$ & $\begin{array}{l}\mathrm{Pb} \\
\left(\mathrm{ng} \cdot \mathrm{m}^{-3}\right)\end{array}$ & $\begin{array}{l}\mathrm{Zn} \\
\left(\mathrm{ng} \cdot \mathrm{m}^{-3}\right)\end{array}$ & $\mathrm{V} / \mathrm{Pb}$ & $\mathrm{V} / \mathrm{Zn}$ \\
\hline This study (high V values) & 11.3 & 130 & 148 & 0.27 & 0.26 \\
This study (low V values) & 1.70 & 37.3 & 30.5 & 0.11 & 0.09 \\
Beijing (Zhao et al., 2013b) & 3.30 & 142 & 324 & 0.02 & 0.01 \\
Shijiazhuang (Zhao et al., 2013b) & 3.80 & 298 & 678 & 0.01 & 0.01 \\
Tianjin (winter) (Gu et al., 2011) & 2.20 & 231 & 339 & 0.01 & 0.01 \\
Zhengzhou (Geng et al., 2013) & 3.70 & 124 & 444 & 0.03 & 0.01 \\
\hline
\end{tabular}

ambient air, but as far away from the port. In addition to the decreased density of ships, exhaust emissions were also diluted by diffusion effect, both of which led to the decrease of contribution of shipping emissions to ambient air. There were 1.0699 million fishing boats (Chinese Fishery Statistical Yearbook, 2013) in China by 2013, much more than 178,500 of water transport vessels (China Statistical Yearbook, 2013), and the fuel used in fishing boats is usually not heavy fuel oil but a kind of mixture with residual oil and diesel. Because we can't confirm the tracers of fishing boats in this study, concentration of primary $\mathrm{PM}_{2.5}$ could not be quantified by the equation mentioned above, so the results about shipping emissions to total $\mathrm{PM}_{2.5}$ may be the minimum values at Tuoji Island.

The temporal variations of primary $\mathrm{PM}_{2.5}$ estimated by shipping emissions and its contribution to total primary $\mathrm{PM}_{2.5}$ shows as follows: it had an increased trend since January, reaching a peak in April. After keeping relatively stable during May and July which was slightly lower than April, they increased again and reached a second peak in September, decreasing thereafter to the minimum value in December. Contribution of primary $\mathrm{PM}_{2.5}$ estimate to total primary $\mathrm{PM}_{2.5}$ had a trend that firstly increase and then decrease. Combined with the meteorological conditions of Tuoji Island, south or southwest wind were the dominant wind since April, activities of the vessels were increasing, which led to the higher values lasted from late spring to autumn. Besides, the winds were decreasing without the influence of the cold air from the north, which would be more suitable for shipping. There were relatively lower values both of the primary $\mathrm{PM}_{2.5}$ estimate and its contribution to total primary $\mathrm{PM}_{2.5}$ in ambient air in summer than April and August, and we inferred that the closed fishing may had a certain influence on them. But on the contrary, summer was also the greatest activity season for ferry ships and cargo ships because of the tourism activities, which relatively offset some of the influence of fishing boats, and it still had higher values in summer than other seasons. As mentioned above, the sea ice in Bohai Sea and the bad weather in winter made it more difficult for shipping, which caused the lower values of primary $\mathrm{PM}_{2.5}$ estimate of shipping emissions. But on the other hand, NCP had the worst contamination in winter, and it still had relatively high concentration of $\mathrm{PM}_{2.5}$ at Tuoji Island through
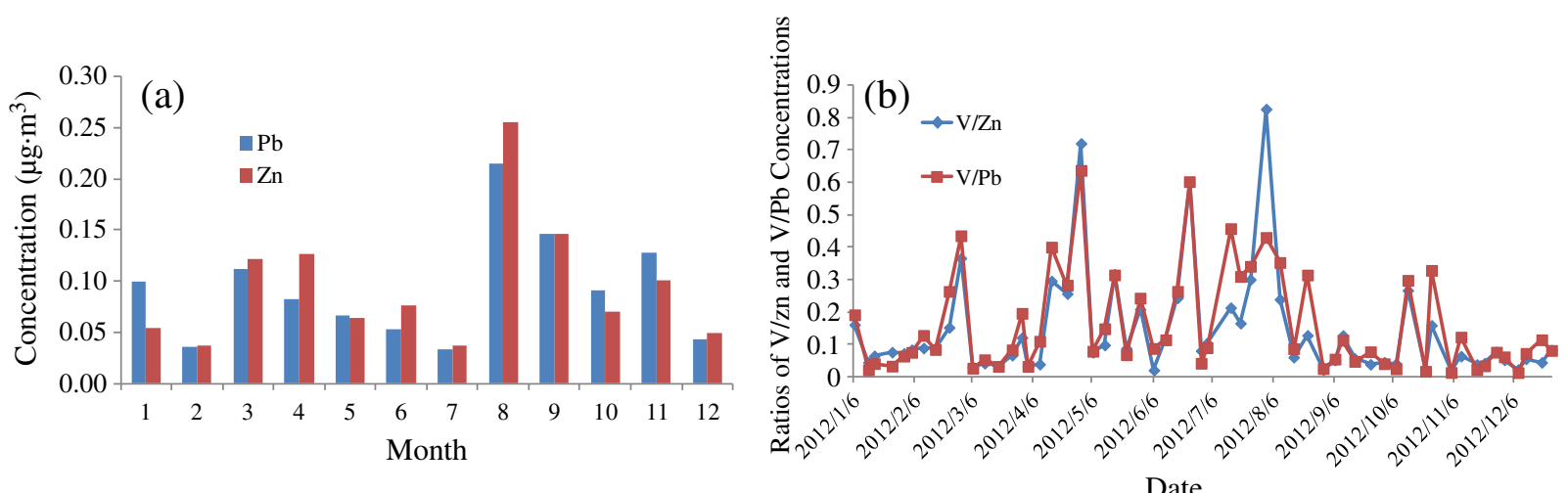

Fig. 5. Concentrations of $\mathrm{Pb}$ and $\mathrm{Zn}$ in $\mathrm{PM}_{2.5}$ in 2012 (a) and the temporal variations of $\mathrm{V} / \mathrm{Pb}$ and $\mathrm{V} / \mathrm{Zn}$ (b) at Tuoji Island. 


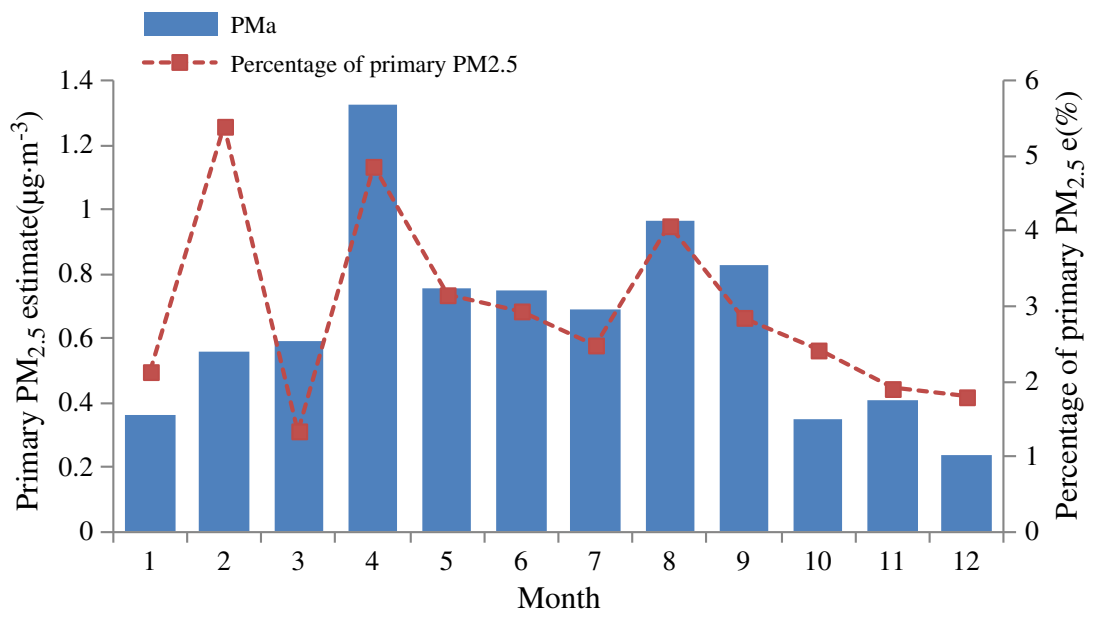

Fig. 6. Concentration of primary $\mathrm{PM}_{2.5}$ estimate of shipping emissions and its contribution to total primary $\mathrm{PM}_{2.5}$ in ambient air at Tuoji Island.

long-distance transport. Therefore, contribution of primary $\mathrm{PM}_{2.5}$ estimate to total primary $\mathrm{PM}_{2.5}$ was lower in winter.

\subsection{Primary $P M_{2.5}$ estimate of shipping emissions in coastal zone of northern China}

Table 4 shows the concentrations of $\mathrm{V}$ and the primary $\mathrm{PM}_{2.5}$ estimate of shipping emissions in coastal zone of northern China using the calculation method above. Comparing the data of aerosol that collected in Bohai Sea, Yellow Sea and offshore areas, the concentrations of $\mathrm{V}$ in total suspended particulates (TSP) were still in a very low level from 1989 to 2000 , which were ranged between 1.4 and $3.4 \mathrm{ng} \cdot \mathrm{m}^{-3}$ with the primary $\mathrm{PM}_{2.5}$ estimate of shipping emissions of $0.15 \mu \mathrm{g} \cdot \mathrm{m}^{-3}$ to $0.37 \mu \mathrm{g} \cdot \mathrm{m}^{-3}$. Besides, the concentration of $\mathrm{V}$ in continental sea was always higher than the open sea. The average concentration of $\mathrm{V}$ was $6.0 \mathrm{ng} \cdot \mathrm{m}^{-3}$ at Tuoji Island, and had showed an obvious growth trend compared with those of previous studies.

Furthermore, because there are more ships in port area and the shipping emissions had direct influence on port cities, which was far greater than the influence caused by long-distance transport of sea area. Took Tianjin and Qingdao, two coastal port cities in the Bohai Rim, for examples, the concentrations of $\mathrm{V}$ in both cities showed increasing trend over time, especially in Qingdao. The concentration of $\mathrm{V}$ in aerosol in Qingdao rapidly increased from $13 \mathrm{ng} \cdot \mathrm{m}^{-3}$ in 2002 to $70 \mathrm{ng} \cdot \mathrm{m}^{-3}$ in 2012, and the primary $\mathrm{PM}_{2.5}$ estimate of shipping emissions reached to $7.48 \mu \mathrm{g} \cdot \mathrm{m}^{-3}$. According to the report of (EPA, 2009), human health would face great challenge if people had long time of high concentration of shipping emissions exposure. For now, there are more than 20 ports that can handle 100 million tons cargoes every

Table 4

Concentrations of $\mathrm{V}$ in aerosols of coastal cities in China and their primary $\mathrm{PM}_{2.5}$ estimate of shipping emissions.

\begin{tabular}{lrll}
\hline & $\begin{array}{l}\text { Sampling } \\
\text { time }\end{array}$ & $\begin{array}{l}\mathrm{V} \\
\left(\mathrm{ng} \cdot \mathrm{m}^{-3}\right)\end{array}$ & $\begin{array}{l}\text { Primary } \mathrm{PM}_{2.5} \\
\text { estimate } \\
\left(\mu \mathrm{g} \cdot \mathrm{m}^{-3}\right)\end{array}$ \\
\hline This study & 2012 & 6.00 & 0.64 \\
Bohai Sea (Sheng et al., 2005) & 2000 & 2.00 & 0.21 \\
Huanghai Sea (Liu and Zhang, 1998) & $1995-1996$ & 1.40 & 0.15 \\
Offshore areas of China (Yang et al., 1994) & 1989 & 1.60 & 0.17 \\
Coastal of Dalian (Li et al., 1997) & $1994-1995$ & 3.40 & 0.37 \\
North Yellow Sea (Wang et al., 2013) & $2006-2007$ & 8.20 & 0.88 \\
Tianjin (Gu et al., 2011) & 2008 & 2.40 & 0.26 \\
Tianjin (Zhao et al., 2013b) & $2009-2010$ & 4.90 & 0.53 \\
Qingdao (Guo et al., 2004) & 2002 & 13.0 & 1.39 \\
Qingdao (Wu et al., 2013) & $2011-2012$ & 70.0 & 7.48 \\
\hline
\end{tabular}

year in China, especially in the Bohai Rim area, cargo handling capacity of port has an annual growth of over $10 \%$ on average (http://info.bfb56. com/news/54297.html). It can be seen from the China Statistical Yearbook (China Statistical Yearbook, 2013) that the total capacity of the major ports had rapidly increased from 293 to 665,000 megaton during 2005 to 2012. Especially the fishing boats that usually have navigation inshore had increased from 548,000 to 1,070,000 during 2006 to 2013, which have much more influence on coastal atmosphere. Therefore, influence of shipping emissions on the ambient air will be more and more serious in coastal area. But there are still no definite emission inventories of shipping emissions in China, and also lacking of oil standards of ships and shipping emissions standards. So further studies of shipping emissions such as emission factors of typical ships in China are imperative, and the emissions-cutting measures of shipping emissions are needed to formulate as soon as possible.

\section{Conclusions}

The average concentration of $\mathrm{PM}_{2.5}$ observed at Tuoji Island was $54.6 \mu \mathrm{g} \cdot \mathrm{m}^{-3}$, with maximum concentration in spring $\left(73.6 \mu \mathrm{g} \cdot \mathrm{m}^{-3}\right)$ and minimum in winter $\left(39.0 \mu \mathrm{g} \cdot \mathrm{m}^{-3}\right)$. Back trajectory air mass analysis together with temporal distribution of $V$ suggests that $V$ could be the tracer of shipping emissions at Tuoji Island. High average ratio of $\mathrm{V} / \mathrm{Ni}$ (1.54) at Tuoji Island compared to 0.7 of industrial sources, also support the role of $\mathrm{V}$ in $\mathrm{PM}_{2.5}$. Besides, high average ratio of $\mathrm{V} / \mathrm{Pb}(0.27)$ or $\mathrm{V} / \mathrm{Zn}$ (0.26) indicated that shipping emissions could have obvious influence on $\mathrm{PM}_{2.5}$ of Tuoji Island.

The results of quantification of shipping emissions to $\mathrm{PM}_{2.5}$ at Tuoji Island suggested that primary $\mathrm{PM}_{2.5}$ estimate accounted for $0.40 \%$ to $11.76 \%$ of total primary $\mathrm{PM}_{2.5}$ at Tuoji Island, with an average contribution of $2.94 \%$, which was lower than other regions in China. Statistical analysis of $\mathrm{V}$ and their primary $\mathrm{PM}_{2.5}$ estimate in aerosols of coastal zone in northern China showed that shipping emissions had a growing impact on ambient air in coastal zone. Further studies on shipping emissions such as emission factors of typical ships in China are imperative, and the emissions-cutting measures of shipping emissions are needed to explore more in this direction.

\section{Acknowledgments}

This work was supported by the CAS Strategic Priority Research Program (No. XDB05030303), and the Natural Scientific Foundation of China (No. 41273135). The authors gratefully acknowledge the National Oceanic and Atmospheric Administration's Air Resources Laboratory for providing the HYSPLIT transport model and the READY website (http:// www.arl.noaa.gov/ready.html). Thanks for the help of Dr. Ishwar 
Chandra Yadav from Guangzhou Institute of Geochemistry Chinese Academy of Sciences on language, and the two anonymous reviewers for their helpful comments.

\section{References}

Agrawal H, Eden R, Zhang X, Fine PM, Katzenstein A, Miller JW, et al. Primary particulate matter from ocean-going engines in the Southern California Air Basin. Environ Sci Technol 2009;43:5398-402.

Almeida SM, Pio CA, Freitas MC, Reis MA, Trancoso MA. Source apportionment of fine and coarse particulate matter in a sub-urban area at the Western European Coast. Atmos Environ 2005;39:3127-38.

Boynard A, Clerbaux C, Clarisse L, Safieddine S, Pommier M, Van Damme M, et al. First simultaneous space measurements of atmospheric pollutants in the boundary laye from IASI: a case study in the North China Plain. Geophys Res Lett 2014;41:645-51.

Brimblecombe P. Air composition and chemistry. Cambridge University Press; 1996

Cao J-J, Shen Z-X, Chow JC, Watson JG, Lee S-C, Tie X-X, et al. Winter and summer $\mathrm{PM}_{2.5}$ chemical compositions in fourteen Chinese cities. J Air Waste Manage Assoc 2012; 62:1214-26.

Cheng S, Lang J, Zhou Y, Han L, Wang G, Chen D. A new monitoring-simulation-source apportionment approach for investigating the vehicular emission contribution to the $\mathrm{PM}_{25}$ pollution in Beijing, China. Atmos Environ 2013;79:308-16.

China Statistical Yearbook. Part XVI: transport, post and telecommunication services; 2013

Chinese Fishery Statistical Yearbook. Part III: production factors; 2013.

Corbett JJ, Winebrake JJ, Green EH, Kasibhatla P, Eyring V, Lauer A. Mortality from ship emissions: a global assessment. Environ Sci Technol 2007;41:8512-8.

Duan J, Tan J, Cheng D, Bi X, Deng W, Sheng G, et al. Sources and characteristics of carbonaceous aerosol in two largest cities in Pearl River Delta Region, China. Atmos Environ 2007;41:2895-903.

EPA. Technical Support Document, Chapter 3: impacts of shipping emissions on air quality, health and the environment. Proposal to designate an emission control area for nitrogen oxides, sulfur oxides and particulate matter; 2009.

Eyring V, Isaksen ISA, Berntsen T, Collins WJ, Corbett JJ, Endresen O, et al. Transport impacts on atmosphere and climate: shipping. Atmos Environ 2010;44:4735-71.

Geng N, Wang J, Xu Y, Zhang W, Chen C, Zhang R. $\mathrm{PM}_{2.5}$ in an industrial district of Zhengzhou, China: chemical composition and source apportionment. Particuology 2013;11:99-109.

Gu J, Bai Z, Li W, Wu L, Liu A, Dong H, et al. Chemical composition of $\mathrm{PM}_{2.5}$ during winter in Tianjin, China. Particuology 2011;9:215-21.

Guo ZG, Feng JL, Fang M, Chen HY, Lau KH. The elemental and organic characteristics of $\mathrm{PM}_{2.5}$ in Asian dust episodes in Qingdao, China, 2002. Atmos Environ 2004;38: 909-19.

Guo H, Ding AJ, So KL, Ayoko G, Li YS, Hung WT. Receptor modeling of source apportionment of Hong Kong aerosols and the implication of urban and regional contribution. Atmos Environ 2009; 43:1159-69.

Han B, Kong S, Bai Z, Du G, Bi T, Li X, et al. Characterization of elemental species in $\mathrm{PM}_{2.5}$ samples collected in four cities of Northeast China. Water Air Soil Pollut 2010;209: $15-28$.

Harrison RM, Smith DJT, Luhana L. Source apportionment of atmospheric polycyclic aromatic hydrocarbons collected from an urban location in Birmingham, UK. Environ Sci Technol 1996;30:825-32.

Healy RM, Hellebust S, Kourtchev I, Allanic A, O'Connor IP, Bell JM, et al. Source apportionment of $\mathrm{PM}_{2.5}$ in Cork Harbour, Ireland using a combination of single particle mass spectrometry and quantitative semi-continuous measurements. Atmos Chem Phys 2010;10: 9593-613.

Hope BK. A dynamic model for the global cycling of anthropogenic vanadium. Globa Biogeochem Cycles 2008;22.

Isakson J, Persson TA, Lindgren ES. Identification and assessment of ship emissions and their effects in the harbour of G(o)over-circleteborg, Sweden. Atmos Environ 2001, 35:3659-66.

Kim KH, Mishra VK, Kang CH, Choi KC, Kim YJ, Kim DS, et al. The metallic composition of aerosols at three monitoring sites in Korea during winter 2002. Environ Monit Assess 2006;121:381-99.
Kwok R, Fung JCH, Lau AKH, Wang ZS. Tracking emission sources of sulfur and elemental carbon in Hong Kong/Pearl River Delta region. J Atmos Chem 2012;69:1-22.

Li L, Li J, Fan G, Zhou K. Sources analysis of marine aerosol in the atmosphere at Dalian Sea area. Chongqing Environ Sci 1997;19:18-23.

Li X, Wang Y, Guo X, Wang Y. Seasonal variation and source apportionment of organic and inorganic compounds in $\mathrm{PM}_{2.5}$ and $\mathrm{PM}_{10}$ particulates in Beijing, China. J Environ Sci (China) 2013;25:741-50.

Liu C, Zhang J. Study on the characteristics of the aerosol and atmospheric flux of the heavy metals over the Yellow Sea. Mar Environ Sci 1998;17:1-6.

Moon KJ, Han JS, Ghim YS, Kim YJ. Source apportionment of fine carbonaceous particles by positive matrix factorization at Gosan background site in East Asia. Environ Int 2008;34:654-64.

Moreno N, Viana M, Pandolfi M, Alastuey A, Querol X, Chinchon S, et al. Determination of direct and fugitive PM emissions in a Mediterranean harbour by means of classic and novel tracer methods. J Environ Manage 2009;91:133-41.

Nguyen HT, Kang CH, Ma CJ, Choi K-C, Kim JS, et al. Evidence of long-range transport of pollutants from the size-fractionated ionic composition of aerosols in the Jeju Island of Korea. Water Air Soil Pollut 2009;196:225-43.

Pacyna JM, Semb A, Hanssen JE. Emission and long-range transport of trace elements in Europe. Tellus B 1984;36:163-78.

Pandolfi M, Gonzalez-Castanedo Y, Alastuey A, de la Rosa JD, Mantilla E, Sanchez de la Campa $\mathrm{A}$, et al. Source apportionment of $\mathrm{PM}_{10}$ and $\mathrm{PM}_{25}$ at multiple sites in the strait of Gibraltar by PMF: impact of shipping emissions. Environ Sci Pollut Res 2011;18: 260-9.

Pey J, Perez N, Cortes J, Alastuey A, Querol X. Chemical fingerprint and impact of shipping emissions over a western Mediterranean metropolis: primary and aged contributions. Sci Total Environ 2013;463:497-507.

Report on China Shipping Development. Part III: port service; 2010.

Shahsavani A, Naddafi K, Haghighifard NJ, Mesdaghinia A, Yunesian M, Nabizadeh R, et al. Characterization of ionic composition of TSP and $\mathrm{PM}_{10}$ during the Middle Eastern Dust (MED) storms in Ahvaz, Iran. Environ Monit Assess 2012;184:6683-92.

Sheng L, Guo Z, Gao H, Zhang Y, Chen H. Preliminary study on element composition and source apportionment of atmospheric aerosol over Bohai Sea. Environ Monitor China 2005;21:16-21.

Tao M, Chen L, Wang Z, Ma P, Tao J, Jia S. A study of urban pollution and haze clouds over northern China during the dusty season based on satellite and surface observations. Atmos Environ 2014;82:183-92.

Wang X, Bi X, Sheng G, Fu H. Hospital indoor $\mathrm{PM}_{10} / \mathrm{PM}_{2.5}$ and associated trace elements in Guangzhou, China. Sci Total Environ 2006;366:124-35.

Wang L, Qi JH, Shi JH, Chen XJ, Gao HW. Source apportionment of particulate pollutants in the atmosphere over the Northern Yellow Sea. Atmos Environ 2013;70:425-34.

Wu H, Zhang C, Wang J, Xuan Z, Chu C, Feng Y, et al. Comparative study on pollution characteristics and source apportionment of $\mathrm{PM}_{10}$ and $\mathrm{PM}_{2.5}$ in Qingdao. Res Environ Scie 2013;26:583-9.

Wu S, Deng F, Wei H, Huang J, Wang X, Hao Y, et al. Association of cardiopulmonary health effects with source-appointed ambient fine particulate in Beijing, China: a combined analysis from the Healthy Volunteer Natural Relocation (HVNR) study. Environ Sci Technol 2014;48:3438-48.

Yang S, Yang Y, Chen B, Zhou M, Lv N, Yu H, et al. Input of atmospheric trace elements to the near-China ocean. Environ Chem 1994;13:382-8.

Yu L. Study on atmospheric deposition of inorganic nitrogen in Qingdao and over China Sea. Ocean University of China; 2007.

Zhang H, Li J, Ying Q, Yu JZ, Wu D, Cheng Y, et al. Source apportionment of $\mathrm{PM}_{25}$ nitrate and sulfate in China using a source-oriented chemical transport model. Atmos Environ 2012;62:228-42.

Zhao M, Zhang Y, Ma W, Fu Q, Yang X, Li C, et al. Characteristics and ship traffic source identification of air pollutants in China's largest port. Atmos Environ 2013a;64: 277-86.

Zhao PS, Dong F, He D, Zhao XJ, Zhang XL, Zhang WZ, et al. Characteristics of concentrations and chemical compositions for $\mathrm{PM}_{2.5}$ in the region of Beijing, Tianjin, and Hebei, China. Atmos Chem Phys 2013b;13:4631-44.

Zheng Y, Twng Y. Emission characteristics of vanadium in air. Environ Sci Manag 2012;37: $20-4$.

Zheng M, Cheng Y, Zeng L, Zhang Y. Developing chemical signatures of particulate air pollution in the Pearl River Delta region, China. J Environ Sci (China) 2011;23:1143-9. 